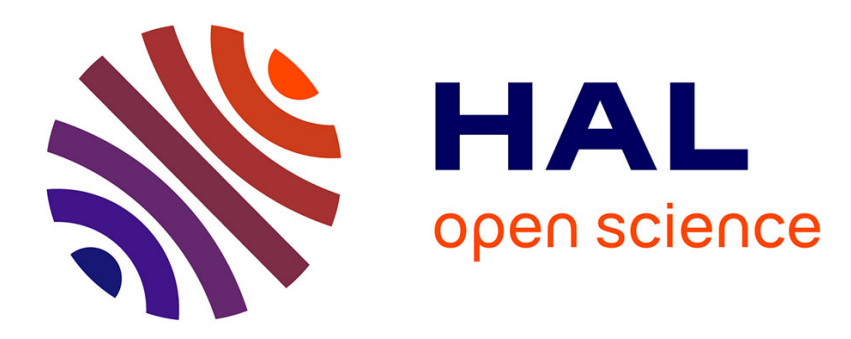

\title{
Morphology Map of Bainites in 2\% Si Steels
}

H. Okamoto, M. Oka

\section{To cite this version:}

H. Okamoto, M. Oka. Morphology Map of Bainites in 2\% Si Steels. Journal de Physique IV Proceedings, 1995, 05 (C8), pp.C8-509-C8-514. 10.1051/jp4:1995878 . jpa-00254127

\section{HAL Id: jpa-00254127 https://hal.science/jpa-00254127}

Submitted on 1 Jan 1995

HAL is a multi-disciplinary open access archive for the deposit and dissemination of scientific research documents, whether they are published or not. The documents may come from teaching and research institutions in France or abroad, or from public or private research centers.
L'archive ouverte pluridisciplinaire HAL, est destinée au dépôt et à la diffusion de documents scientifiques de niveau recherche, publiés ou non, émanant des établissements d'enseignement et de recherche français ou étrangers, des laboratoires publics ou privés. 


\title{
Morphology Map of Bainites in 2\% Si Steels
}

\author{
H. Okamoto and M. Oka
}

Department of Mechanical Engineering, Tottori University, Koyama, Tottori 680, Japan

\begin{abstract}
A metallographic study of isothermal transformation products formed at the early stage of transformation was made in silicon alloyed high-carbon steels ( $\mathrm{C}$ wt $\%=0.6,0.8,1.1$ and 1.4 ) in the temperature range between 700 and $200{ }^{\circ} \mathrm{C}$. Observations are summarized as a "morphology map" showing the formation temperature-carbon content fields of isothermal transformation products. In all steels investigated, the proeutectoid ferrite, upper bainite and lower bainite are formed at temperatures below the extrapolated $\mathrm{A}_{3}$ line and above $600{ }^{\circ} \mathrm{C}$, between 550 and 400 ${ }^{\circ} \mathrm{C}$, and below $350{ }^{\circ} \mathrm{C}$ and above the $\mathrm{Ms}$ temperature, respectively. The microstructural-Bs temperature and the transition temperature from upper bainite to lower bainite are independent of the bulk carbon content, and around 550 and $350{ }^{\circ} \mathrm{C}$, respectively. It is shown that above results can be explained by a diffusional model for the proeutectoid ferrite formation and a displacive model for the bainite formation.
\end{abstract}

\section{INTRODUCTION}

The transformation mechanism of bainite has been a topic of discussion[1], and antipodal models (diffusional or displacive) have been proposed. The diffusion controlled reaction model[2] describes the bainitic reaction as an extension of the proeutectoid ferrite reaction. By this model, the bainite must be observed in the stable or metastable $(\alpha+\gamma)$ two-phase field in the phase diagram. By a displacive model[3] including the statistical fluctuation of carbon concentration in the austenite, on the other hand, the bainite in an $\mathrm{Fe}-\mathrm{M}-\mathrm{C}$ ternary alloy (M: a substitutional element) should be formed at temperatures below the $\mathrm{Ms}$ temperature of an $\mathrm{Fe}-\mathrm{M}$ binary alloy, which is the alloy with carbon atoms removed from the ternary alloy, and the Bs temperature is independent of the bulk carbon content.

The present results indicate that the bainitic ferrite develops by the displacive mechanism rather than the diffusional mechanism.

\section{EXPERIMENTAL}

The chemical compositions of the steels used are given in Table 1 along with their Ms temperatures which were determined metallographically. Specimens of $17 \times 12 \mathrm{~mm}$ in size were cut from hot rolled and grounded plates of $1 \mathrm{~mm}$ thickness. Austenitizing was carried out at Acm $+60^{\circ} \mathrm{C}$ for $10 \mathrm{~min}$ under dynamically evacuated conditions. The specimens were quenched in a $\mathrm{Pb}$ bath at temperatures between 700 and $600{ }^{\circ} \mathrm{C}$ or in an inert $\mathrm{NaNO}_{2}-\mathrm{KNO}_{3}$ bath at temperatures between 550 and $200^{\circ} \mathrm{C}$, transformed for various periods of time, and finally quenched into water. Specimens for light and SEM metallography were etched with $2 \%$ nital. 
Table 1 Chemical compositions (wt\%) and Ms temperatures $\left({ }^{\circ} \mathrm{C}\right.$ ) of the steels investigated

\begin{tabular}{ccccccc}
\hline Steel & $\mathrm{C}$ & $\mathrm{Si}$ & $\mathrm{Mn}$ & $\mathrm{P}$ & $\mathrm{S}$ & $\mathrm{Ms}$ \\
\hline $\mathrm{Fe}-2 \mathrm{Si}-0.3 \mathrm{C}$ & 0.304 & 1.99 & tr. & 0.006 & 0.001 & 330 \\
$\mathrm{Fe}-2 \mathrm{Si}-0.6 \mathrm{C}$ & 0.616 & 2.01 & tr. & 0.004 & 0.001 & 270 \\
$\mathrm{Fe}-2 \mathrm{Si}-0.8 \mathrm{C}$ & 0.789 & 2.020 & tr. & 0.003 & 0.004 & 240 \\
$\mathrm{Fe}-2 \mathrm{Si}-1.1 \mathrm{C}$ & 1.118 & 2.089 & tr. & 0.002 & 0.003 & 175 \\
$\mathrm{Fe}-2 \mathrm{Si}-1.4 \mathrm{C}$ & $\mathbf{1 . 3 9 4}$ & 2.045 & tr. & 0.002 & 0.003 & 150 \\
\hline
\end{tabular}

\section{RESULTS}

Figs. 1(a)-(d) show microstructures of isothermal transformation products at relatively early stage of transformation at $600,500,400$ and $300^{\circ} \mathrm{C}$ in the $\mathrm{Fe}-2 \mathrm{Si}-0.6 \mathrm{C}$ steel. At $600{ }^{\circ} \mathrm{C}$, the pearlite (P) and the proeutectoid ferrite (PF) form as shown in Fig. 1(a). The matrix is martensite formed from untransformed austenite on quenching from the isothermal holding temperature. At 500 and $400{ }^{\circ} \mathrm{C}$ (Figs. 1(b) and (c)), the morphology of the product is markedly different from that of the proeutectoid ferrite. The shape of the product resembles a letter " - " of kanji. This structure has been called "upper bainite" in other investigation of silicon steels[4]. The $300{ }^{\circ} \mathrm{C}$ product (Fig. 1(d)) characterized by a fine line is the "lower bainite" in silicon steels[4]. The same microstructural changes caused by decreasing the isothermal transformation temperature are shown in Figs. 2 to 4 for $\mathrm{Fe}-2 \mathrm{Si}-0.8,1.1$ and $1.4 \% \mathrm{C}$ steels, respectively.

The results of microstructural observation throughout the temperature range 700 to $200{ }^{\circ} \mathrm{C}$ are summarized as a "morphology map" in Fig. 5. Marks $\diamond, \diamond, \bigcirc$ and $\Delta$ in Figs. 5 are placed at temperature-carbon content coordinate at which the peralite, pearlite + proeutectoid ferrite, upper bainite and lower bainite were detected. As indicated in Fig. 5, it can be seen that (i) the bainite has its own formation temperature range different from that of proeutectoid ferrite, (ii) the microstructural-Bs temperature is about $550{ }^{\circ} \mathrm{C}$ and independent of the bulk carbon content, and (iii) the transition of bainite morphology from the upper bainite to the lower bainite occurs about $350{ }^{\circ} \mathrm{C}$, and this is also independent of the bulk carbon content.

Excepting the transition temperature of bainite morphology, these results are in good agreement with that reported in $2 \mathrm{Si}-1 \mathrm{Mn}-0.34 \mathrm{C}$ and $2 \mathrm{Si}-1 \mathrm{Mn}-0.59 \mathrm{C}$ steels[5].

\section{DISCUSSION}

According to the displacive model[3], the carbon poor zones in the parent austenite are formed as a results of statistical fluctuation of carbon concentration. When the Ms temperature in these zones rises up to the isothermal transformation temperature, the bainite nucleates martensitically. This model predicts that the Bs temperature of an $\mathrm{Fe}-2 \mathrm{Si}-\mathrm{C}$ ternary alloy corresponds to the $\mathrm{Ms}$ temperature of the $\mathrm{Fe}-2 \mathrm{Si}$ binary alloy, and is independent of the bulk carbon content. Ms temperatures in Fig. 5 were determined metallographically. The upper and lower error bars represent the lowest temperature at which martensite was not observed and the highest temperature at which martensite was observed, respectively. The Ms temperature extrapolated linearly to the zero carbon content is $400{ }^{\circ} \mathrm{C}$, and does not correspond to the microstructural-Bs temperature. However, the Ms temperature rises as shown by a dashed line in Fig. 5 because it rises rapidly in ultra-low carbon steels[6]. Thus, it is explained that the Bs temperature is a constant of $550^{\circ} \mathrm{C}$ by the displacive mechanism[3].

It can also be explained the transition temperature of bainite morphology by the displacive model as follows. Figs. 6(a) and (b) show the three-dimensional shapes of upper and lower bainites, respectively. A plane-1 and plane-2 are perpendicular to each other. The edge of the two planes is represented by $\mathrm{W}-\mathrm{E}$. The two planes were observed by a scanning electron microscope 

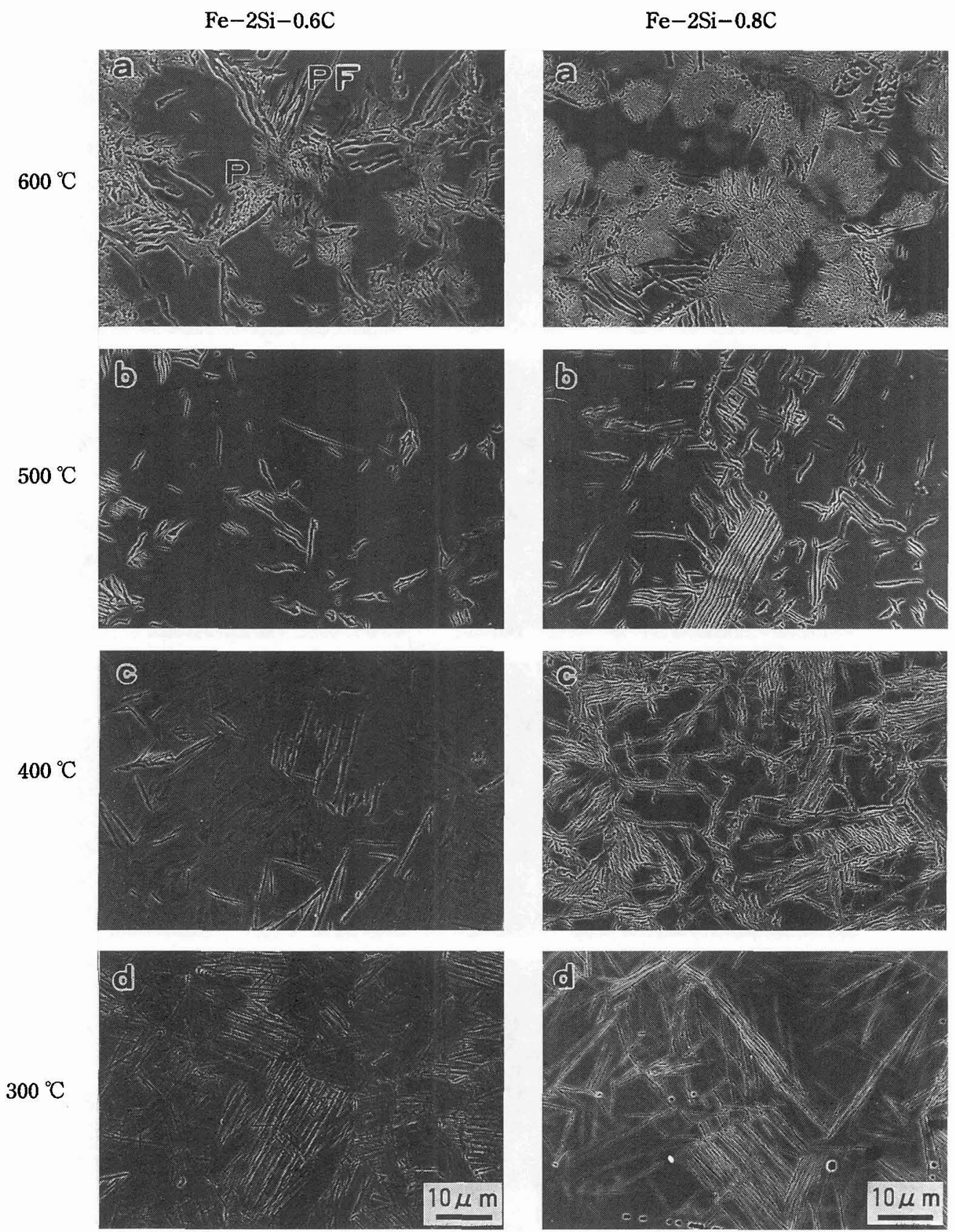

Fig.1 Scanning electron micrographs of isothermal transformation products in an $\mathrm{Fe}-2 \mathrm{Si}-0.6 \mathrm{C}$ steel. (a) $600{ }^{\circ} \mathrm{C} 10 \mathrm{~s}$, (b) $500{ }^{\circ} \mathrm{C} 10 \mathrm{~s}$, (c) $400^{\circ} \mathrm{C} 15 \mathrm{~s}$, (d) $300^{\circ} \mathrm{C}$ $30 \mathrm{~s}$.

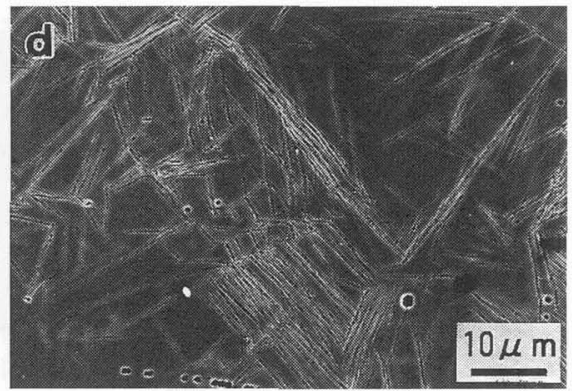

Fig.2 Scanning electron micrographs of isothermal transformation products in an $\mathrm{Fe}-2 \mathrm{Si}-0.8 \mathrm{C}$ steel. (a) $600{ }^{\circ} \mathrm{C} 10 \mathrm{~s}$, (b) $500^{\circ} \mathrm{C} 20 \mathrm{~s}$, (c) $400^{\circ} \mathrm{C} 45 \mathrm{~s}$, (d) $300^{\circ} \mathrm{C}$ 255s. 

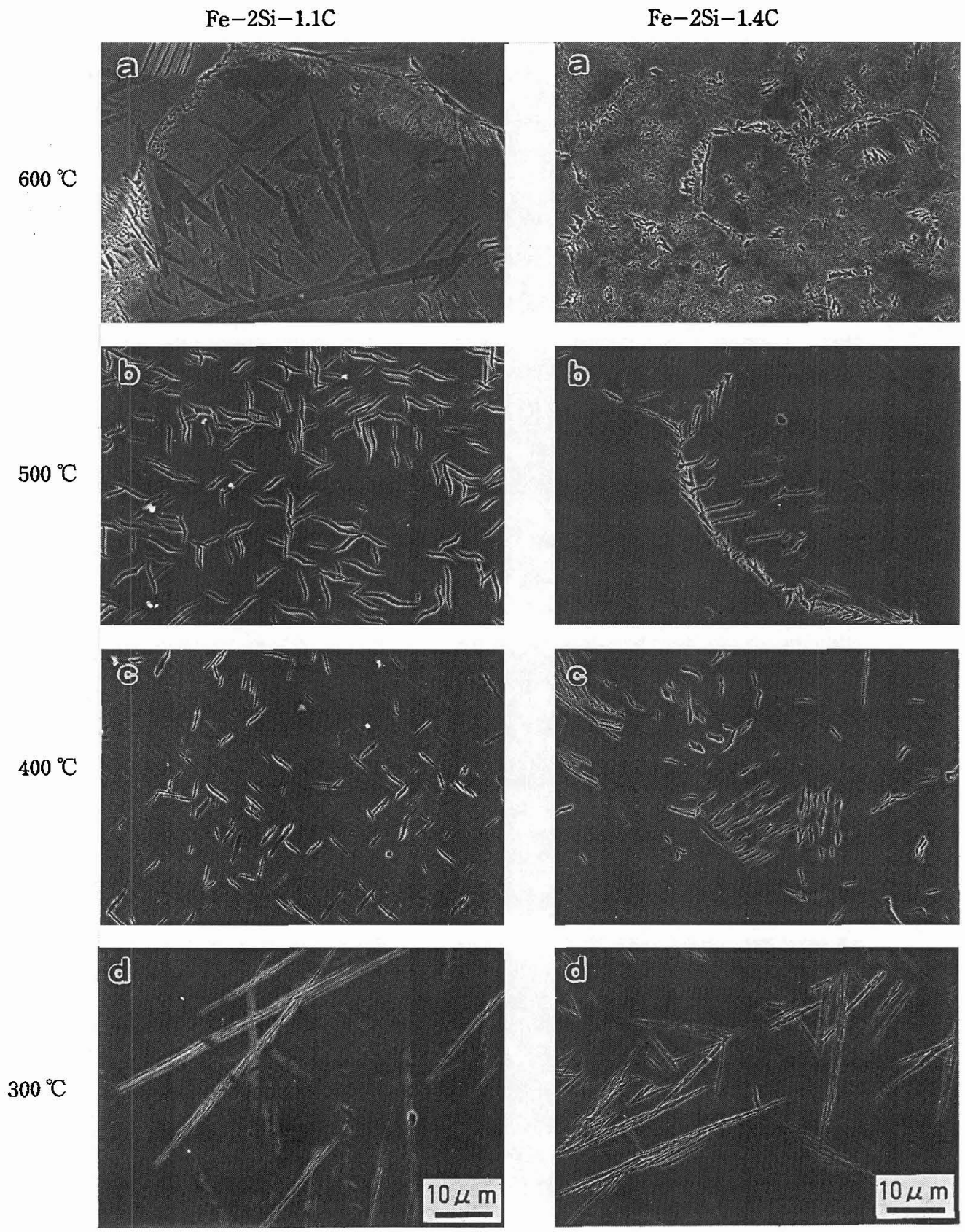

Fig.3 Scanning electron micrographs of isothermal transformation products in an $\mathrm{Fe}-2 \mathrm{Si}-1.1 \mathrm{C}$ steel. (a) $600{ }^{\circ} \mathrm{C} 10 \mathrm{~s}$, (b) $500{ }^{\circ} \mathrm{C} 45 \mathrm{~s}$, (c) $400{ }^{\circ} \mathrm{C} 120 \mathrm{~s}$, (d) $300{ }^{\circ} \mathrm{C}$ 600 s.

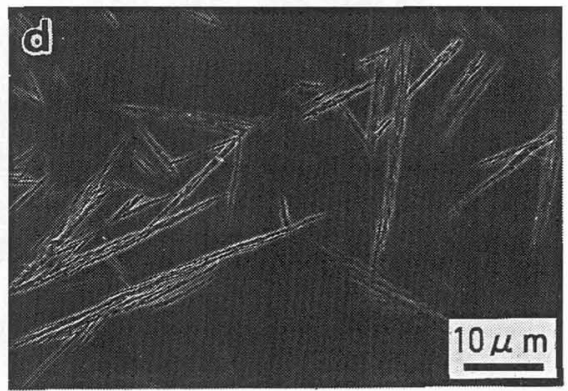

Fig.4 Scanning electron micrographs of isothermal transformation products in an $\mathrm{Fe}-2 \mathrm{Si}-1.4 \mathrm{C}$ steel. (a) $600^{\circ} \mathrm{C} 20 \mathrm{~s}$, (b) $500{ }^{\circ} \mathrm{C} 90 \mathrm{~s}$, (c) $400{ }^{\circ} \mathrm{C} 1200 \mathrm{~s}$, (d) $300{ }^{\circ} \mathrm{C}$ 1080 s. 


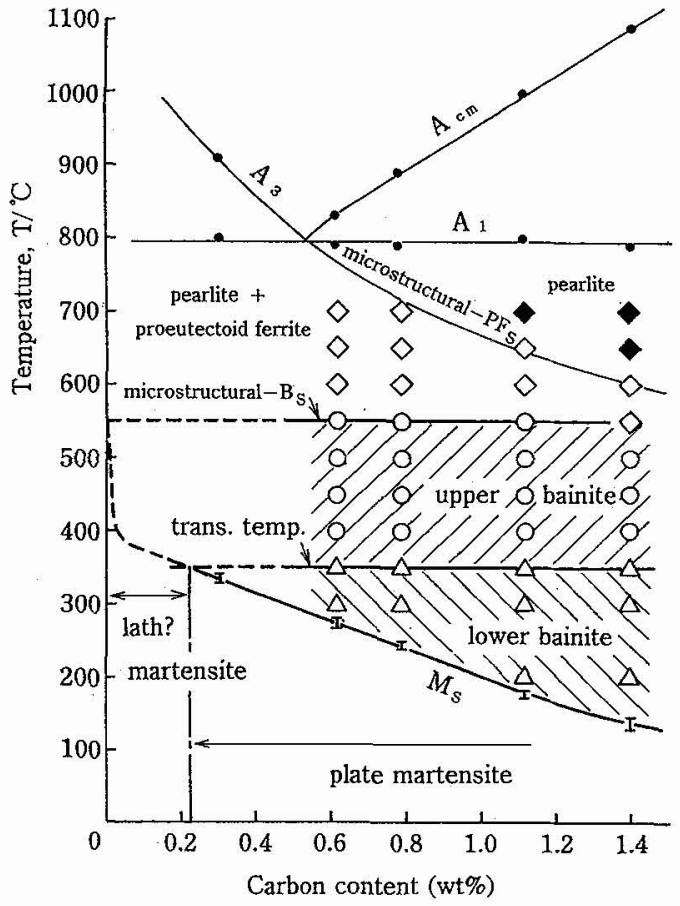

Fig. 5 Morphology map of isothermal transformation products in $\mathrm{Fe}-2 \mathrm{Si}-\mathrm{C}$ steels. Marks $\diamond, \diamond, 0$ and $\triangle$ represent the pearlite, pearlite + proeutectoid ferrite, upper bainite and lower bainite, respectively.
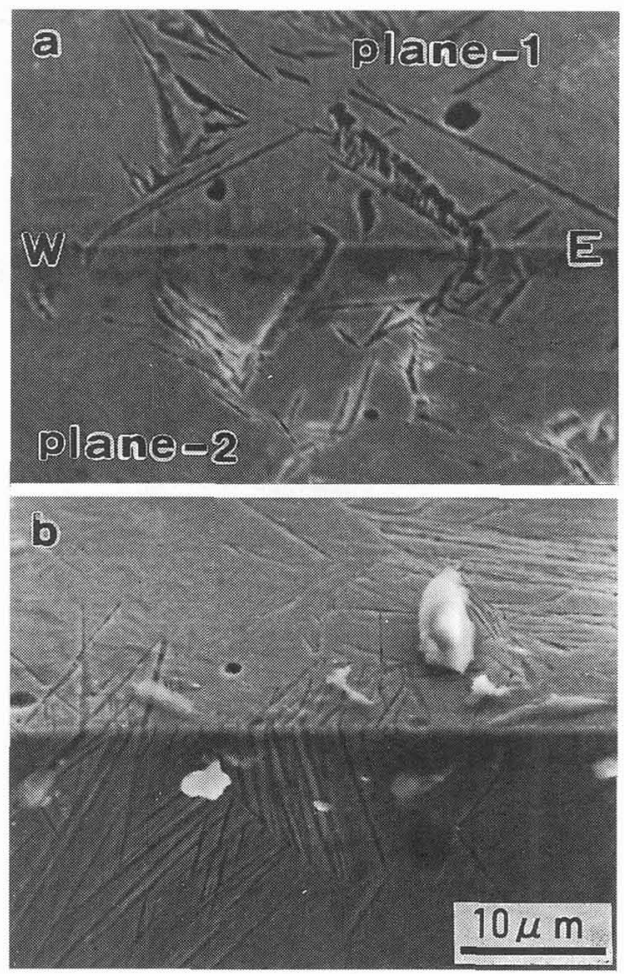

Fig. 6 Two surface SEM micrographs showing three dimensional shape of bainites formed in an $\mathrm{Fe}-2 \mathrm{Si}-$ $0.8 \mathrm{C}$ steel. (a) lath shaped upper bainite, $400{ }^{\circ} \mathrm{C}$, $165 \mathrm{~s}$, (b) plate shaped lower bainite, $300^{\circ} \mathrm{C}, 190 \mathrm{~s}$.

with long focal distance. It can be seen that the three-dimensional shapes of the upper and lower bainites are the lath and plate, respectively. The morphology of bainites varies with their formation temperature.

The morphology of martensite, however, depends on the bulk carbon contents, and is a lath in plain low carbon steels and a plate in plain high carbon steels[7]. The morphology of martensites in the present steels with $2 \%$ silicon is plate. Figs. 7(a) and (b) show the examples in the $\mathrm{Fe}-2 \mathrm{Si}-0.3 \mathrm{C}$ and $\mathrm{Fe}-2 \mathrm{Si}-0.6 \mathrm{C}$ steels. Therefore, the lath martensite will be formed below $0.3 \%$ carbon in $2 \%$ silicon alloyed steels. The critical carbon content at which the martensite morphology varies from plate to lath will be about $0.2 \% \mathrm{C}$ as shown in Fig. 5 .

From the morphological similarity between the bainite and martensite, we propose a new mechanism on the transition between the upper and lower bainites. "If the carbon concentration at the nucleation site of bainite is as low as that forms the lath martensite, the lath shaped bainite, i.e., the upper bainite is formed. If it is as high as that forms plate martensite, the plate shaped bainite, i.e., the lower bainite, is formed." Based on the above proposal, we can explain that the transition temperature of bainite morphology is $350^{\circ} \mathrm{C}$ because the critical carbon content at which martensite morphology varies from plate to lath is about $0.2 \% \mathrm{C}$, and the $\mathrm{Ms}$ temperature is independent of the bulk carbon content since the statistical fluctuation of carbon concentration in austenite is assumed.

The proeutectoid ferrite and pearlite are observed in a temperature range higher than that of bainites. However, the proeutectoid ferrite was not observed at $700{ }^{\circ} \mathrm{C}$ in the $\mathrm{Fe}-2 \mathrm{Si}-1.1 \mathrm{C}$ steel and above $650{ }^{\circ} \mathrm{C}$ in the $\mathrm{Fe}-2 \mathrm{Si}-1.4 \mathrm{C}$ steel as shown in Fig. 5. The $\mathrm{A}_{1}, \mathrm{~A}_{3}$ and $\mathrm{Acm}$ lines in 

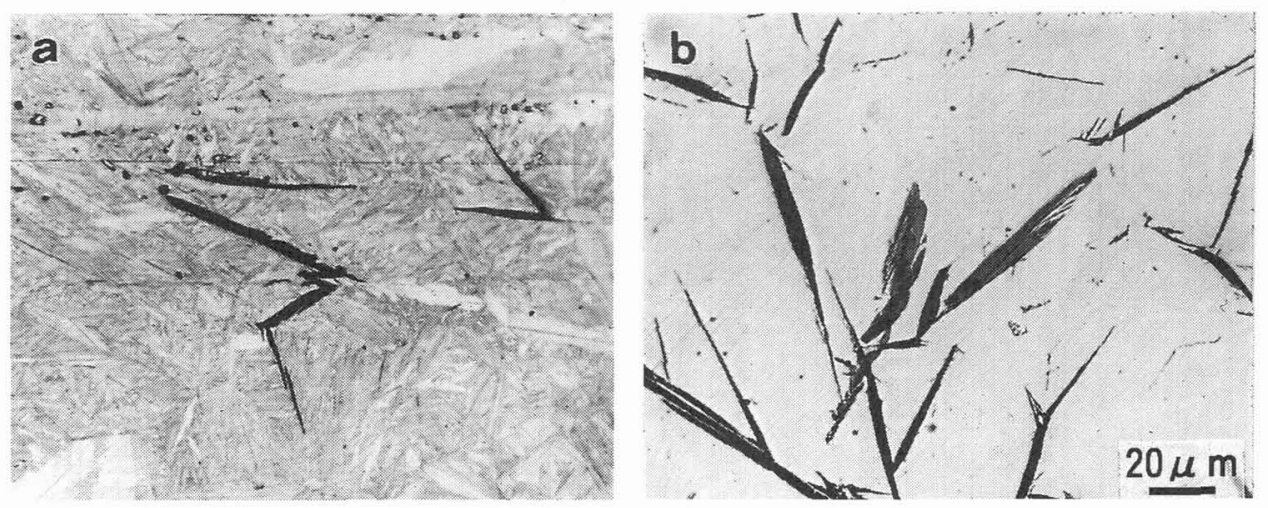

Fig. 7 Optical micrographs showing the morphology of martensite formed just below the Ms temperature is plate. (a) $\mathrm{Fe}-2 \mathrm{Si}-0.3 \mathrm{C}$ steel, (b) $\mathrm{Fe}-2 \mathrm{Si}-0.6 \mathrm{C}$ steel.

Fig. 5 were determined by dilatometric measurements. The microstructural-PFs temperature is the highest temperature at which the proeutectoid ferrite is observed. The microstructural-PFs line and the $\mathrm{A}_{3}$ line are connected smoothly. This means that the microstructrural-PFs line corresponds to the metastable extrapolated $\mathrm{A}_{3}$ line. The facts that the proeutectoid ferrite forms in the metastable $(\alpha+\gamma)$ two-phase field, and the highest temperature at which the proeutectoid ferrite is observed corresponds to the extrapolated $\mathrm{A}_{3}$ line can be explained by the diffusional model[2] as described in the introduction.

\section{SUMMARY}

A metallographic study of isothermal transformation products was made in $2 \%$ silicon alloyed high-carbon steels $\left(\mathrm{C} \%=0.6,0.8,1.1\right.$ and 1.4) in the temperature range between 700 and $200^{\circ} \mathrm{C}$. It was shown that the proeutectoid ferrite transforms diffusively, but the bainite nucleates displacively. From the morphological similarity between the bainite and martensite, we proposed a new mechanism on the transition between the upper and lower bainites as follows. "If the carbon concentration at the nucleation site of bainite is as low as that forms the lath martensite, the lathshaped bainite, i.e., the upper bainite, is formed. If it is as high as that forms plate martensite, the plate-shaped bainite, i.e., the lower bainite, is formed."

\section{References}

[1] Hehemann R.F., Kinsman K.R. and Aaronson H.I., Metall. Trans., 3(1972)1077-1093.

[2] Kinsman K.R. and Aaronson H.I., Transformation and Hardenability in Steels, Climax Molybdenum Co., Ann Arbor, MI, (1967)33-38.

[3] Tsuzaki K., Fujiwara K. and Maki T., Materials Trans. JMM, 32(1991)667-678.

[4] Sandvik B.P.J., Metall. Trans., 13A(1982)777-787.

[5] Tsuzaki K., Nakao C. and Maki T., Materials Trans.,JIM, 32(1991)658-666.

[6] Bibby M.J. and Parr J.G., J. Iron Steel Inst., 202(1964)100.

[7] Marder A.R. and Krauss G, Trans. ASM,60(1967)651-660. 